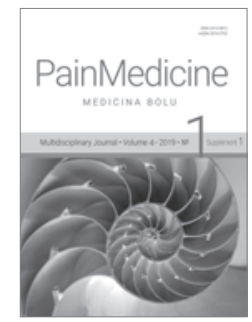

DOI: $10.31636 /$ pmjua.t2.13

\title{
Випадок епізодичної пароксизмальної гемікранії. Особливості диференційної діагностики
}

\author{
Білошицький В. В. \\ Інститут нейрохірургії ім. акад. А. П. Ромоданова НАМН України, Київ, Україна
}

Чоловік, 28 років, звернувся на консультацію зі скаргами на напади інтенсивного нестерпного (VAS 10) головного болю, які турбують з 19-річного віку. Зі слів пацієнта, тривалість нападів болю - 15-30 хвилин, частота протягом доби - 2-3 вдень і 4 вночі, в тому числі 2 напади виникають в один і той самий час - о 2-й годині ночі та о 7-8-й годині ранку. Останній напад піднімає пацієнта від сну. Серії нападів можуть виникати до 2 разів на рік, найчастіше в кінці весни або в кінці осені. Тривалість серії нападів може становити від 2-3 днів до 3 місяців, проміжки між серіями нападів (ремісії) можуть становити від 5 місяців до 2-3 років.

Під час попередніх серій біль турбував у правій скроневій ділянці, правому оці, ділянці правої вилиці та верхньої щелепи справа. Під час нападів відзначає почервоніння ока, сльозотечу, відчуття закладання правої половини носа. Остання серія нападів почалася за 2 тижні до консультації, при цьому болі змістилися в ділянку лівої скроні й лівого ока (біль поміняв сторону - це буде прокоментовано окремо).

Під час нападів збуджений (ажитація). Не палить зараз і не палив у минулому. Прийом алкоголю може посилити больові відчуття.

Пацієнт повідомив, що в минулому через нестерпність болю була спроба самогубства.

Неврологічно: без особливостей. На представлених МРТ головного мозку відзначається вогнище лікворної щільності розмірами $0,9 \times 1,9 \times 1,8$ см у правій скроневолобовій ділянці конвекситально (розміри без динаміки), нерівномірно розширені конвекситальні підпавутинні простори, одиничне вогнище гліозу в правій лобовій ділянці.

Клінічна картина, на наш погляд, передбачала необхідність диференційної діагностики між епізодичним кластерним головним болем і епізодичною пароксизмальною гемікранією. Більше схилялися почати 3 рекомендацій щодо абортивного й превентивного лікування кластерного головного болю, враховуючи більшу частоту патології і наявність багатьох характерних клінічних ознак. Пояснюючи пацієнту можливість блокади потиличних нервів, яка, відповідно до даних досліджень, може значно полегшити стан при обох цефалгіях (при кластерному головному болю в 58 \% випадків), почали пальпацію точок проекції потиличних нервів (необхідна частина обстеження при цефалгіях). Відзначено різку болючість (jump sign) у проекції великого потиличного нерва зліва, пальпація спровокувала напад нестерпного болю в ділянці ока й скроні зліва з почервонінням склери тривалістю до 2 хвилин, у подальшому протягом 10-15 хвилин ще два подібних напади. Враховуючи те, що короткі напади характерні для пароксизмальної гемікранії, пацієнтові рекомендований негайний прийом індометацину в дозі 50 мг, у подальшому - по 25 мг 3 рази на добу. Через 1-1,5 години після прийому індометацину нападів немає, пацієнт спокійний. Детальне розпитування хворого виявило, що серед попередніх кластерів болю, які загалом відповідали описаним характеристикам, було дві серії численних про- 
тягом доби (не зміг назвати точну кількість) коротких нападів (тривалістю близько 2 хвилин) особливо нестерпного болю. Одна 3 цих серій трапилась під час призову до армії, завершилася спробою суїциду, госпіталізацією до військового госпіталю і згодом - до психіатричного стаціонару на 3 місяці. Наступний кластер тривав 1 тиждень і завершився госпіталізацією до реанімації з введенням у медикаментозний сон.

Зустріч наступного дня показала, що на фоні прийому індометацину напади припинилися, ніч провів спокійно. Рекомендовано продовжувати прийом індометацину в дозі 25 мг 3 рази на добу протягом кількох тижнів 3 подальшою консультацією. Діагноз: Епізодична пароксизмальна гемікранія (п. 3.2.1 ICHD-3).

Критерії діагностики пароксизмальної гемікранії відповідно до Міжнародної класифікації головного болю ICHD-3:
А. Як мінімум 20 нападів, що відповідають критеріям B-E.

В. Напади інтенсивного одностороннього болю орбітальної, супраорбітальної або скроневої локалізації, тривалістю 2-30 хвилин.

С. Принаймні один з наступних симптомів або ознак, іпсилатеральний до болю:

- ін'єкція кон'юнктиви та/або сльозотеча;

- закладення носа та/або ринорея;

- набряк повік;

- потіння лоба та обличчя;

- почервоніння лоба та обличчя;

- відчуття закладення вуха;

- міоз та/або птоз.

D. Атаки мають частоту більше п'яти на день протягом більше половини часу.

Е. Напади повністю попереджаються терапевтичними дозами індометацину.

F. Не пояснюються краще іншими діагнозами ICHD-3. 